\title{
PENERAPAN JASA PINJAMAN DALAM SIMPAN PINJAM DI KOPERASI
}

\author{
Alif Ilham Akbar Fatriansyah \\ STIE Al-Madani Bandar Lampung, Indonesia \\ Email: alifatriansyah@ymail.com
}

\begin{abstract}
Application of Loan Services in Savings and Loans in Cooperatives. Loan Services are part of the Cooperative within the Savings and Loan business unit, which resulted in inconsistencies in the application of a principle, whether the cooperative is based on sharia principles or conventional principles that will result in deviation. This can be reflected because the loan service that has been happening in the Savings and Loans Cooperative is a combination of Al-Qardh representing the principles of sharia and debt representing the conventional principle.
\end{abstract}

Keywords: Service Loan, Inconsistency, Al-Qardh, and Debt.

Abstrak. Penerapan Jasa Pinjaman Dalam Simpan Pinjam di Koperasi. Jasa Pinjaman merupakan bagian dari Koperasi didalam unit usaha Simpan Pinjam, yang dihasikan atas ketidakkonsistenan dalam penerapan suatu prinsip, apakah koperasi menggunakan prinsip syariah atau prinsip konvensional sehingga akan menghasilkan penyimpangan. Hal ini bisa tercermin karena jasa pinjaman yang selama ini terjadi di Koperasi Simpan Pinjam merupakan gabungan dari Al-Qardh yang mewakili dari prinsip syariah dan Hutang yang mewakili dari prinsip konvensional.

Kata Kunci: Jasa Pinjaman, Ketidakkonsistenan, Al-Qardh, dan Hutang. 


\section{PENDAHULUAN}

Dalam setiap koperasi di Indonesia, banyak sekali yang memiliki unit usaha simpan pinjam, bahkan mayoritas memiliki unit usaha tersebut, baik yang prinsip konvensional ataupun prinsip syariah, walaupun begitu simpan pinjam merupakan asal usul berdirinya koperasi di Indonesia. Unit usaha ini semakin populer karena bisa menarik para nasabah yang berminat meminjam uang tanpa syarat yang banyak seperti di Bank. Pada tata caranya simpan pinjam di Bank dan di Koperasi tidak berbeda jauh, jika koperasi proses dan syarat tidak lebih banyak seperti di Bank. Dalam unit usaha simpan pinjam koperasi mendapatkan pemasukan, yaitu dengan adanya jasa pinjaman, jasa pinjaman sendiri merupakan upah atau bayaran lebih yang harus dikeluarkan anggota selain pinjaman pokok, dengan jumlah tertentu dan waktu yang telah disepakati.

Secara tersirat dalam penjelasan di atas kita bisa membayangkan bahwa sebenarnya jasa pinjaman tidak berbeda atau bahkan sama dengan bunga yang di Bank. Seperti halnya bank, jasa pinjaman terkadang menilai dengan perhitungan suku bunga bank, walaupun ada juga koperasi yang memiliki perhitungan sendiri. Dalam kesadaran ini peneliti ingin mengetahui lebih dalam mengapa hal ini bisa terjadi, padahal sudah kita tahu bahwa tambahan atas hutang piutang masih banyak pro dan kontranya. Sesungguhnya jasa pinjaman ini tidak hanya terjadi di koperasi konvensional namun juga melanda di koperasi syariah.

Fenomena jasa pinjaman sebenarnya banyak terjadi di koperasi konvensional, namun dalam perkembangannya ternyata digunakan juga dalam koperasi syariah. Nominal besarnya "jasa pinjaman" antara koperasi syariah maupun konvensional berbeda-beda. Besar atau kecilnya jasa pinjaman ternyata berpengaruh terhadap pembagian SHU (sisa hasil usaha) yang akan diterima oleh anggota, semakin aktif anggota dalam menggunakan unit usaha simpan pinjam, semakin besar SHU (sisa hasil usaha) yang diterima.

Sebenarnya Islam melarang adanya penambahan pembayaran terhadap hutang piutang, salah satu dampak buruknya bisa dimanfaatkan untuk mendapatkan keuntungan padahal peminjam sedang mengalami kesulitan. Dalam Al-Quran, Allah SWT berfirman sebagai berikut: 
Alif Ilham Akbar. F: Penerapan Jasa Pinjaman...

"Dan jika (orang yang berhutang itu) dalam kesukaran, maka berilah tangguh sampai dia berkelapangan, dan menyedekahkan (sebagai atau semua utang) itu, lebih baik bagimu, jika kamu mengetahuinya" (Al-Baqarah:280).

"Hai orang-orang yang beriman, janganlah kamu saling memakan harta sesamamu dengan jalan yang batil (tidak benar), kecuali dengan jalan perniagaan yang berlaku dengan suka sama suka di antara kamu. Dan janganlah kamu membunuh dirimu. Sungguh, Allah Maha Penyayang kepadamu" (An-Nisa:29).

Dalam firman Allah SWT surat Al-Baqarah (2) ayat 275 sampai 281 yang intinya melarang mengambil "riba" dan menyatakan mereka dalam keadaan berperang dengan Allah dan Rasul-Nya serta memerintahkan kaum muslim untuk meninggalkan semua "riba", memerintahkan mereka untuk hanya mengambil jumlah pokok pinjaman saja, dan membebaskan jika peminjam mengalami kesulitan. Dari penjelasan ayat diatas, ditegaskan bahwa dilarang adanya pengambilan tambahan biaya atas pinjaman dan hanya mengambil sejumlah yang dipinjam atau pinjaman pokok.

Fakta lain dari simpan pinjam sebenarnya memiliki tujuan untuk membantu anggota yang ingin mendapatkan pinjaman dengan proses mudah dan cepat hal ini yang menjadi pertimbangan adanya unit usaha ini, selain itu menurut Saktijaningdijah (2016) kelebihan koperasi simpan pinjam dibandingkan bank antara lain seperti menimbulkan suasana keakraban antar anggota, syarat yang mudah, serta angsuran ringan dengan pembayaran melalui pemotongan gaji bulanan (jika anggota merupakan karyawan atau pegawai suatu instansi), sehingga melakukan pinjaman di koperasi memiliki nilai lebih jika dibandingkan dengan di bank, contohnya anggota melakukan pinjaman karena kebutuhan masuk rumah sakit yang terkesan tidak terduga, jika di bank proses akan lama belum lagi prosedur yang dilakukan banyak, kalau di koperasi kemungkinan besar tidak lama. Menurut Soedarso (2011) kegiatan usaha pembiayaan anggota dalam bentuk tunai masuk dalam kategori sebagai unit simpan pinjam (USP). 
Dalam penelitian yang mengatakan bahwa "jasa pinjaman" adalah riba disampaikan oleh Susamto (2013) "riba" dalam praktik keuangan identik dengan "bunga", lingkup keharaman sistem "bunga" termasuk dalam koperasi yang menyelenggarakan simpan pinjam dengan kegiatan utama usaha simpan pinjam, istilah "riba" secara bahasa berarti tambahan, dengan kata lain riba artinya tumbuh dan membesar, sehingga bisa diasumsikan bahwa ketika meminjam sejumlah tersebut, kita harus mengembalikan pinjaman dengan jumlah yang berbeda, hal ini apakah tidak menimbulkan beban tersendiri bagi orang yang meminjam.

Fenomena lainnya muncul ketika peneliti melakukan observasi di situs penelitian ditemukanlah perbedaan persepsi tentang "jasa pinjaman" dari anggota, ketika salah satu anggota menyadari adanya ketidaklarasan dengan apa yang dipelajari selama ini dan mengatakan bahwa ini tidak tepat (menyimpang), tapi anggota lain menyatakan berbeda beranggapan bahwa anggota dilibatkan dalam keputusan ini tepat (tidak menyimpang). Seharusnya alasan pokok keberadaan prinsip ekonomi Islam adanya keinginan dari masyarakat muslim untuk taat dalam ajaran Islam dengan menjalankan seluruh aktifitas dan transaksi ekonomi sesuai dengan ketentuan syariah. Padahal perekonomian sejak zaman Nabi Muhammad SAW banyak menggunakan landasan pertukaran antara barang dan jasa yang salah satu kegiatan ekonominya terdiri dari dua pilar yaitu pertukaran objek yang fikih dengan dibedakan jenis dan waktu pertukarannya (Muliya, dan Imaniyati, 2008:110).

Berdasarkan pendapat dari Muheramtohadi (2017) lembaga keuangan yang berbentuk syariah (LKS) seharusnya badan yang bergerak di bidang keuangan dilandaskan pada ajaran Islam bersumber pada Al-Quran dan As-Sunnah disertai pendapat para ahli ekonomi Islam. Lembaga keuangan syariah tidak semata-mata berorientasi keuntungan tapi harus dilandasi unsur ke Islaman, hal ini dibenarkan oleh Wildaniyati (2006) yang mengungkapkan setiap transaksi harus memenuhi prinsip-prinsip di semua aspek seperti proses transaksi melibatkan moral, pola perilaku, tata cara hingga pemilihan bentuk pembiayaan yang sesuai dengan syariah Islam.

Jika dilihat dari substansinya wajar jika koperasi tidak menjalankan prinsip sesuai dengan ekonomi Islam karena setiap unit usaha ataupun kegiatan dalam koperasi ini harus berorientasi terhadap toleransi antar umat beragama. Hal ini 132 
Alif Ilham Akbar. F: Penerapan Jasa Pinjaman...

dipertegas oleh Nur (2015) nilai agama sebenarnya memberi warna dan pengaruh dalam pengembangan entitas syariah di Indonesia, akan tetapi mengaplikasikan keyakinan nilai agama ke dalam institusi sosial tidaklah mudah dan membutuhkan waktu apalagi atmosfir politik mempengaruhi, oleh sebab itu walaupun mayoritas beranggotakan beragama Islam, namun ada beberapa koperasi tidak diberi nama "syariah", mungkin ini salah satu alasan kebijakan yang digunakan tidak menerapkan prinsip ekonomi Islam secara menyeluruh.

Terlepas dari baik atau buruknya tren sebutan "syariah", sebaiknya bersandar pada kesadaran bahwa sebutan itu sebenarnya bukan keharusan, melainkan penyesuaian tren (Manunggal, 2011). Melihat fenomena perekonomian dunia yang telah berubah dari waktu ke waktu sesuai dengan perkembangan zaman ditambah dengan perubahan teknologi informasi yang semakin berkembang pesat, sehingga banyak nilai-nilai baru yang dibentuk namun sulit untuk menentukan mana yang benar dan salah, terkadang membingungkan masyarakat (anggota koperasi) apakah membawa kebaikan atau keburukan, apakah benar atau salah, walaupun begitu banyak juga masyarakat yang tidak peduli akan hal tersebut mungkin karena tidak terlalu berpengaruh dalam hidupnya. Dinamika kehidupan yang terjadi dalam masyarakat menyebabkan setiap orang memiliki kemampuan berbeda-beda dalam menyikapi fenomena. Padahal menurut Mulawarman (2005) syariah Islam dicanangkan demi kebahagiaan manusia, lahir batin, dunia ukhrawi, mencerminkan prinsip kemaslahatan, dan yang lebih dari kemaslahatan adalah "keadilan sosial".

Menurut pendapat Soedarso (2011) penilaian terhadap organisasi koperasi harus secara keseluruhan, harapan yang didapat untuk bisa mengingatkan peranan dan fungsi dari koperasi baik konvensional atau syariah yang tidak hanya berorientasi pada profit oriented tetapi juga non profit oriented, karena masyarakat masih beranggapan bahwa organisasi yang baik dilihat dari aspek keuangan atau material. Ini menunjukkan ketika orientasi terhadap keuangan atau material maka prinsip atau aturan yang ada bisa saja dilanggar, tergantung dari ketaatan terhadap prinsipnya.

Berdasarkan hasil pengamatan terhadap penelitian terdahulu yang ada di Indonesia masih jarang ada penelitian tentang jasa pinjaman dalam unit usaha simpan pinjam oleh sebab itu peneliti mengkaji beberapa penelitian seperti Susila 
(2014) penelitiannya mengkaji tentang permodalan yang menghasilkan koperasi BMT bekerjasama dengan UMKM untuk memperluas pasar dan mengembangkan usahanya sehingga berkontribusi besar dalam pemberdayaan ekonomi kerakyatan, sedangkan penelitian Manunggal (2011) mengkaji tentang ekonomi dan manajemen keuangan syariah yang dipahami sebagai khazanah dan karya para ekonom muslim sebagai pengejawantahan nilai-nilai ajaran ekonomi Al-Quran dan Hadits dalam tataran kehidupan kemasyarakatan, seperti nilai harta benda, nilai kepemilikian, nilai pembagian kerja, sistem harga, harga yang adil, kekuatan permintaan dan penawaran, konsumsi dan produksi, pertambahan penduduk, pengeluaran dan perpajakan pemerintah, peranan negara, lintas perdagangan, monopoli, pengendalian harga, pendapatan dan pengeluaran rumah tangga dan lain-lain semua itu tidak terlepas begitu saja dari ekonomi konvension.

Dilema menggunakan prinsip dalam koperasi khususnya di bawah naungan Kementerian Agama menjadi isu yang menarik, disatu sisi harus bisa sesuai dengan pedoman prinsip, akan tetapi disisi lain apakah prinsip tersebut dapat diterima secara keseluruhan oleh anggota karena perbedaan persepsi dan kesenjangan atas pemahaman, selain itu perbedaan agama menjadi pertimbangan yang tidak boleh dipinggirkan. Mungkin harapan yang diinginkan oleh anggota menggunakan prinsip ekonomi yang tepat bisa menyelesaikan permasalahan yang ada dalam kehidupan tanpa melanggar ketentuan hukum Tuhan Yang Maha Esa.

Penelitian ini berusaha untuk memahami kesadaran yang dimiliki informan dalam suatu fenomena, sehingga fokus penelitian ini adalah mencari makna berdasarkan kesadaran yang dimiliki informan terhadap jasa pinjaman. Berdasarkan pemahaman konsep dan teori disertai realita masing-masing yang pernah terjadi, oleh karena itu peneliti menggunakan pendekatan Interpretif untuk menggali sudut pandang informan terhadap realitas sebenarnya yang telah lama terjadi namun jarang diungkapkan. Metode yang digunakan untuk mengungkapkan dari informan dengan fenomenologi.

\section{METODE PENELITIAN}

Penelitian ini menggunakan metode kualitatif. Metode ini lebih secara subjektif didasarkan atas fakta yang terjadi di situs penelitian. Hal ini dibenarkan oleh Santoso 
Alif Ilham Akbar. F: Penerapan Jasa Pinjaman...

(2016) bahwa penelitian kualitatif diharapkan memiliki pemahaman yang lebih rinci, jelas, akurat dan mendalam tentang temuan, sedangkan menurut Sutama dalam Rahmawati (2015) metode kualitatif lebih diarahkan untuk memahami fenomenafenomena sosial dari perspektif partisipan (membuat teori). Hasil yang diharapkan dapat mampu menjawab pertanyaan penelitian terhadap fenomena yang ada di situs penelitian, tujuan peneliti salah satunya mendapatkan kemurnian atas temuan saat observasi.

Paradigma sebagai sudut pandang atau cara pandang terhadap fenomena yang dilihat dan disadari, sudut pandang informan atas apa yang terjadi. Menurut Kamayanti (2016:13) paradigma merupakan suatu cara pandang mengenai hakikat, sedangkan menurut Syahrina (2016) setiap paradigma mengidentifikasi realitas sosial dengan cara yang berbeda berdasarkan lima asumsi dasar seperti ontologi, epistemologi, human nature, metodologi dan asumsi sifat masyakat. Penelitian ini menggunakan metodologi karena ingin mengekplorasi temuan awal untuk mencapai hasil akhir menemukan sebuah makna sesuai fakta, sehingga dapat disimpulkan bahwa adanya korelasi antara paradigma dan metodologi sebagai cara pandang menyikapi suatu fenomena sosial yang terjadi melalui asumsi subjektif informan.

Dalam paradigma interpretif, berpandangan bahwa realitas sosial dilakukan secara sadar dan secara aktif dibangun sendiri oleh individu, oleh karena itu setiap individu berpotensi memberi jawaban berbeda atas fenomena yang terjadi (Riharjo, 2011). Suatu realitas dari seseorang tidak bisa disamakan dengan orang lain, bahkan realitas sosial merupakan hal yang timbul karena adanya interaksi, penelitian interpretif bertujuan mengeksplorasi interaksi tersebut dengan memperoleh informasi tentang suatu gejala berdasarkan pengalaman dan kesadaran, sehingga dalam mengkontruksi ilmu sosialnya seharusnya tidak fokus pada analisis struktur dunia sosial, tetapi kerangka pikiran seseorang sebagai aktor utama dalam dunia sosial.

Sutrisno dan Hanafi (2004:3) dalam Riharjo (2011) mengatakan prinsip dasar yang dikembangkan dalam paradigma interpretif dengan membaca fenomena terkait individu menyikapi sesuatu yang ada di lingkungannya berdasarkan tingkat kesadaran pada dirinya, menghasilkan makna tersembunyi tanpa disadari berdasarkan interaksi sosialnya dengan hal yang ditemuinya. Hasil dalam fenomena 
seperti itu yang ingin didapatkan oleh peneliti, dengan berpandangan bahwa menemukan makna dalam sebuah subjektif atas kesadaran mengetahui suatu fenomena.

Berdasarkan penjelasan yang sudah diungkapkan, maka penelitian ini menggunakan paradigma interpretif dengan pendekatan fenomenologi. Fenomenologi merupakan sebuah pendekatan filosofis sosial untuk menyelidiki kesadaran manusia yang memiliki pengalaman panjang atas fenomena, dengan melihat interaksi yang diberikan melalui hubungan komunikasi antara peneliti dan informan. Pendekatan fenomenologi transcendental mengungkapkan mengenai kesadaran pada sesuatu, melihat sesuatu, mengingat sesuatu, dan menilai sesuatu. Sesuatu yang dimaksud terkait kesadaran yang telah distimulasi oleh persepsi dari yang nyata dan yang pernah terjadi. Karakter intensionalitas tidak hanya terkait dengan fokus dari tindakan individu yang dialami, tetapi merupakan karakter dasar dari pikiran itu sendiri. Karakter tersebut berlaku untuk kesadaran yang mengarah terhadap satu objek, dilihat dari suatu pandangan yang terjadi di dunia sosial. Kesadaran diri akan timbul dalam merefleksikan sesuatu yang dilihat, dipikirkan, diingat dan dialami.

\section{TEMUAN PENELITIAN}

Makna jasa pinjaman dalam unit usaha simpan pinjam dapat dilihat ketika menganalisis setiap informasi yang diberikan, tidak terlepas dari kesadaran yang melekat pada informan, karena kesadaran merupakan gambaran terhadap pola pikiran dan hati nurani untuk memahami dan mendalami setiap fenomena disekitarnya. Tidak bisa disampingkan begitu saja bahwa sebenarnya realitas yang ada utuh dan berbentuk hierarki, oleh karena itu perlu ada pemahaman yang sejalan dengan konsep awal agar tidak terjadi persimpangan. Hierarki akan kehadiran jasa pinjaman menggambarkan tingkat kesadaran, peran sebagai anggota, dan sifat menentukan dalam rapat, oleh karena itu terdapat perbedaan setiap informan dalam tingkat kesadarannya. Hal ini yang coba peneliti ungkapan sehingga diakhir sub bab ditemukan sebuah makna terdalam.

Dalam temuan penelitian ketika berbicara sistem syariah murni ternyata hanya bisa digunakan untuk usaha, oleh sebab itu opsi yang diperbolehkan jual-beli 
Alif Ilham Akbar. F: Penerapan Jasa Pinjaman...

(murobahah), dimana kebutuhan anggota dibelikan terlebih dahulu oleh koperasi setelah itu dijual kembali keanggota dengan membuat selisih harga sebagai pendapatan dari koperasi, dengan pembayaran disesuaikan kemampuan bersama dalam akad yang disepakati. Hal ini yang seharusnya dipraktikan oleh lembaga keuangan jika menggunakan prinsip syariah untuk menghindari riba, seperti dalam surat berikut: "Allah telah menghalalkan jual beli dan mengharamkan riba" (AlBaqarah:275).

Ketika Allah menghalalkan jual-beli sudah seharusnya umat mematuhi secara seksama sehingga tidak menimbulkan persepsi perbedaan antara praktik dan teori, hal selama ini terjadi dalam jasa pinjaman di unit usaha simpan pinjam bahwa ditemukan mengandung "riba" yang menurut prinsip syariah itu dilarang. Hal itu dapat dilihat dari surat berikut: "Allah memusnakan riba dan menyuburkan sedekah" (Al-Baqarah:276). Sudah sepatutnya jika menerapkan prinsip syariah harus benarbenar menjalankan sesuai dengan kaidahnya.

Yang terjadi dalam koperasi kebanyakan adanya "ketidakkonsistenan" dalam penerapan prinsip antara syariah atau konvensional, penetapan prinsip dalam AD/ART (Anggaran Dasar/Aturan Rumah Tangga) seharusnya diterapkan secara konsisten sampai unit usahanya. Untuk tidak menimbulkan perbedaan persepsi antar anggota, selain itu koperasi harus melakukan sosialisasi terhadap para anggotanya.

Kendala yang terjadi bahwa koperasi di Kementerian Agama yang bertugas untuk menyelenggarakan fungsi pemerintahan dalam pembimbingan dan pengelolaan fungsi administratif dari kegiatan keagamaan di Indonesia, sehingga tidak leluasa untuk menerapkan prinsip syariah atau prinsip konvensional secara utuh, tidak lupa prinsip yang digunakan dalam koperasi harus bertujuan memajukan kesejahteraan anggota pada khususnya dan masyarakat lain pada umumnya, serta ikut membangun tatanan perekonomian nasional dalam rangka mewujudkan masyarakat yang maju, adil, dan makmur berlandaskan Pancasila dan UndangUndang Dasar 1945, bunyi Pasal 3 Undang-Undang Nomor 25 Tahun 1992 Tentang Perkoperasian.

Berdasarkan temuan dari para informan sintesa yang didapat setelah menelaah secara keseluruhan informasi, memaknai bahwa jasa pinjaman merupakan "hasil dari ketidakkonsistenan dalam menggunakan suatu prinsip", yaitu antara menggunakan 
prinsip syariah atau prinsip konvensional, sehingga jasa pinjaman yang selama ini terjadi dianggap sebagai bagian dari syariah yang mengandung riba.

Dalam temuan penelitian didapatkan bahwa adanya ketidakkonsistenan dalam penerapan jasa pinjaman, untuk melihat adanya ketidakkonsistenan tersebut, peneliti akan coba membandingkan hasil temuan dengan teori syariah dan teori konvensional, sehingga hasilnya akan terlihat secara seksama perbedaannya.

Dalam temuan penelitian, jasa pinjaman dikatakan sebagai "ketidakkonsistenan" dikarenakan beberapa hal antara lain; bagian syariah, termasuk bunga, persimpangan antara jasa pinjaman uang dan jual-beli (murabahah), dengan temuan itu terdapat bagian syariah dan bagian dari konvensional. Dalam praktiknya, jasa pinjaman digunakan sebagai sisi komersial dan sisi sosial, pemanfaatan dua sisi tersebut yang membuat celah perbedaan persepsi antara para informan. Untuk mempermudah peneliti mengungkapkan temuan penelitian dalam gambar sebagai berikut.

\section{Temuan Jasa Pinjaman}

\begin{tabular}{|c|c|}
\hline & Jasa Pinjaman \\
\hline Penyelenggara & Koperasi. \\
\hline Sumber dana & $\begin{array}{ll}\text { - } & \text { Simpanan pokok } \\
\text { - } & \text { simpanan wajib }\end{array}$ \\
\hline Jenisnya & $\begin{array}{l}\text { - Pinjaman uang dan } \\
\text { Pinjaman barang. }\end{array}$ \\
\hline Sifat & - $\quad$ Khusus anggota. \\
\hline Aplikasi & $\begin{array}{l}\text { - Uang: Bayar sekolah, } \\
\text { bayar kuliah, bayar sakit, } \\
\text { bangun rumah, usaha, } \\
\text { umroh, haji dan lain-lain. } \\
\text { Barang: pembeliaan } \\
\text { kendaraan. }\end{array}$ \\
\hline Manfaat & $\begin{array}{ll}- & \text { Kebutuhan konsumtif. } \\
\text { - } & \text { Kebutuhan produktif. }\end{array}$ \\
\hline
\end{tabular}


Alif Ilham Akbar. F: Penerapan Jasa Pinjaman...

\begin{tabular}{|l|ll|}
\hline Tujuan & $\bullet$ & Komersil. \\
& $\bullet$ & Sosial. \\
\hline
\end{tabular}

Melihat dari ketidakkonsistenannya yang menggandung syariah dan konvensional, peneliti akan ungkapkan terlebih dahulu dari sisi syariah. Dalam sisi syariah jasa pinjaman di istilahkan dalam bahasa fikih sebagai “Al-qardh" yang berarti meminjam uang ataupun barang atas dasar kepercayaan. Menurut Antonio (2017:131) Al-Qardh adalah pemberian harta kepada orang lain yang dapat ditagih atau diminta kembali, dengan kata lain meminjamkan tanpa mengharapkan imbalan, dalam litelatur fikih qardh dikategorikan dalam aqd tathawwui atau akad saling membantu dan bukan transaksi komersial, sedangkan dalam ungkapan lain Antonio (2017:134) Al-Qardh dapat memberikan manfaat antara lain; membantu nasabah dalam kesulitan mendesak, terkandung misi sosial disamping misi komersial, meningkatkan citra baik dan loyalitas masyarakat terhadap bank syariah. Untuk mempermudah peneliti akan ungkapkan dalam gambar sebagai berikut.

Al-Qardh

\begin{tabular}{|c|c|}
\hline & Al-Qardh \\
\hline Penyelenggara & Lembaga keuangan. \\
\hline Sumber dana & - $\quad$ Uang nasabah. \\
\hline Jenisnya & Pembiayaan uang. \\
\hline Sifat & - $\quad$ Umum. \\
\hline Aplikasi & $\begin{array}{ll}\text { - } & \text { Individu. } \\
\text { - } & \text { Kelompok. }\end{array}$ \\
\hline Manfaat & $\begin{array}{l}\text { - Membantu keuangan } \\
\text { secara cepat dan jangka } \\
\text { pendek. } \\
\text { - } \quad \text { Meningkatkan } \\
\text { kerjasama. } \\
\text { - Meningkatkan loyalitas. }\end{array}$ \\
\hline Tujuan & - $\quad$ Sosial. \\
\hline
\end{tabular}


Selanjutnya dilihat dari sisi konvensional, jasa pinjaman bisa dikatakan sebagai hutang, dalam buku Ekonomi dan Bisnis (2016:31) pasal 1 ayat (12) Undang-Undang Republik Indonesia nomor 7 Tahun 1992 Tentang Perbankan, menyebutkan bahwa:

"Kredit adalah penyediaan uang atau tagihan yang dapat dipersamakan dengan itu, berdasarkan persetujuan atau kesepakatan pinjam-meminjam antara bank dengan pihak lain yang mewajibkan pihak pinjaman untuk melunasi utangnya setelah jangka waktu tertentu dengan jumlah bunga, imbalan atau pembagian hasil keuntungan".

Dalam penjelasan lain dikatakan bahwa menurut Chairuman Pasaribu (1994:136), pengertian hutang sama dengan pengertian "Perjanjian pinjammeminjam", yang dijumpai dalam ketentuan Kitab Undang-Undang Hukum Perdata, yang mana pasal 1754 berbunyi, "pinjam-meminjam adalah suatu perjanjian dengan mana pihak yang satu memberikan kepada pihak yang lain, suatu jumlah ketentuan barang-barang yang menghabis karena pemakaian, dengan syarat bahwa pihak yang belakang ini akan mengembalikan sejumlah sama dari macam keadaan yang sama pula".

Dalam penjelasan konvensional, jasa pinjaman disamakan dengan hutang karena dalam praktek yang terjadi, anggota memiliki "kewajiban" untuk membayar pinjaman pokok ditambah jasanya sehingga ini dianggap sebagai kewajiban yang harus dibayar anggota dengan kata lain anggota secara tidak langsung memiliki hutang, walaupun untuk kebutuhan yang mendesak dan konsumtif, hal ini dibenarkan dalam buku Ekonomi dan Bisnis Islam (2016:29) umumnya, hutang ini muncul atas keperluan konsumsi atau untuk keperluan sehari-hari yang mendesak, sehingga merupakan suatu kegiatan sosial atau tabarru. Untuk menggambarkan pemahaman peneliti, akan diungkapkan dalam gambar berikut.

\section{Hutang}

\begin{tabular}{|l|ll|}
\hline & \multicolumn{1}{|c|}{ Hutang } \\
\hline Penyelenggara & $\bullet$ & Individu \\
& $\bullet$ & Lembaga Keuangan. \\
\hline Sumber dana & $\bullet$ & Individu \\
\hline
\end{tabular}


Alif Ilham Akbar. F: Penerapan Jasa Pinjaman...

\begin{tabular}{|l|ll|}
\hline & $\bullet$ & Lembaga Keuangan. \\
\hline Jenisnya & $\bullet$ & Uang \\
& $\bullet$ & barang. \\
\hline Sifat & $\bullet$ & Umum. \\
\hline Aplikasi & $\bullet$ & Sesuai kebutuhan individu \\
& atau kelompok. \\
\hline Manfaat & $\bullet$ & Konsumtif. \\
& $\bullet$ & Produktif \\
\hline Tujuan & $\bullet$ & Komersil \\
\hline
\end{tabular}

Dalam semua penjelasan diatas untuk mempermudah pemahaman, peneliti membuat gambaran hasil dari temuan dibandingkan dengan Al-Qardh dan hutang sebagai berikut.

Jasa Pinjaman, Al-Qardh dan Hutang

\begin{tabular}{|c|c|c|c|}
\hline & Jasa Pinjaman & Al-Qardh & Hutang \\
\hline Praktik & $\begin{array}{l}\text { Pinjaman } \\
\text { pokok+jasa } \\
\text { pinjaman }\end{array}$ & $\begin{array}{l}\text { Pinjaman tanpa } \\
\text { imbalan }\end{array}$ & $\begin{array}{l}\text { Pinjaman } \\
\text { dengan } \\
\text { tambahan biaya }\end{array}$ \\
\hline Keuntunganya & $\begin{array}{l}\text { Jumlah } \\
\text { pengembalian } \\
\text { bertambah }\end{array}$ & $\begin{array}{l}\text { Jumlah } \\
\text { pengembalian } \\
\text { sama }\end{array}$ & $\begin{array}{l}\text { Jumlah } \\
\text { pengembalian } \\
\text { bertambah }\end{array}$ \\
\hline Jumlah & $\begin{array}{l}\text { Ditentukan } \\
\text { pihak } \\
\text { penyelenggara }\end{array}$ & $\begin{array}{l}\text { Ditentukan } \\
\text { oleh peminjam }\end{array}$ & $\begin{array}{l}\text { Ditentukan } \\
\text { secara bersama }\end{array}$ \\
\hline Tujuan & Pendapatan & $\begin{array}{l}\text { Tolong } \\
\text { menolong }\end{array}$ & Pendapatan \\
\hline Penggunaannya & $\begin{array}{l}\text { Bayar sekolah } \\
\text { Bayar kuliah } \\
\text { Bangun rumah } \\
\text { Pembiayaan }\end{array}$ & $\begin{array}{l}\text { Konsumtif, } \\
\text { mendesak, } \\
\text { jangka pendek }\end{array}$ & $\begin{array}{l}\text { Konsumtif } \\
\text { Produktif }\end{array}$ \\
\hline
\end{tabular}




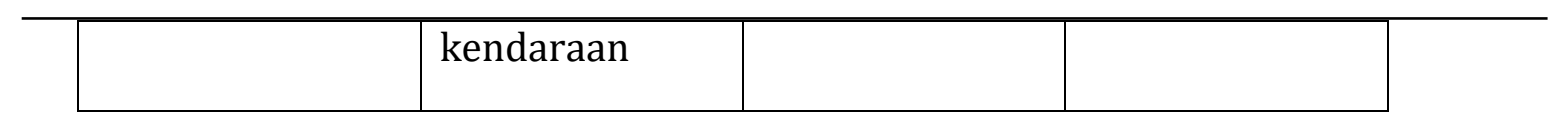

Berdasarkan gambar yang telah dijelaskan diatas, bahwa sebenarnya praktik jasa pinjaman selama ini gabungan antara Al-Qardh dan hutang karena berdasarkan praktik yang terjadi di koperasi, sehingga hasil dari temuan memang menunjukkan terdapat "ketidakkonsistenan" menggunakan suatu prinsip. Hal ini termasuk wajar, jika koperasi berada di dalam lingkup Kementerian Agama Republik Indonesia yang memang menaungi berbagai macam agama sehingga "jasa pinjaman” mengakomodir dari berbagai kepentingan.

Hasil temuan dan membandingkan dengan Al-Qardh dan hutang sesuai dengan penelitian dari Tsabita (2014) dan Rahim (2015), bahwa secara garis besar temuan penelitian terdahulu menyatakan bahwa ini merupakan termasuk bagian dari "penyimpangan", dengan beranggapan bahwa penyimpangan ini terjadi karena memastikan sesuatu yang belum pasti dibuat seakan-akan sudah pasti, padahal perhitungan pokok pinjaman bisa diperhitungkan sesuai dari pemanfaatan/hasil pokoknya.

Dalam tatanan kehidupan jika terjadi "ketidakkonsistenan" akan mengakibatkan "penyimpangan", hal ini merupakan hasil dari sebab dan akibat. Kesadaran informan yang dimaknai oleh peneliti bisa saja dialami dengan anggota lain yang tanpa disadari telah mengakui adanya "ketidakkonsistenan" tersebut, namun tidak kuasa untuk merubahnya. Dalam sebuah organisasi koperasi tidah mudah dalam mengakui bahwa terdapat "penyimpangan" atas apa yang terjadi, sehingga perlu ada kesadaran dari pihak yang terlibat untuk mengakui "ketidakkonsistenan".

\section{DAFTAR PUSTAKA}

Al-Quran digital versi Android. (2014). Tangerang Selatan. Andi Unpam

Husserl, E. (1982). Cartesin Meditations: An Introduction to Phenomenology. Trans. Dorion Cairns. The Hague Boston. London. Martinus Nijhoff Publisher

Kamayanti, A. (2016). Metodologi Penelitian Kualitatif Akuntansi. Pengantar Religiositas Keilmuan. Cetakan Pertama. Yayasan Rumah Peneleh, Jakarta Selatan. 
Alif Ilham Akbar. F: Penerapan Jasa Pinjaman...

Manunggal, S.A.M. (2011). Etika Islam Dalam Manajemen Keuangan. Jurnal Hukum Islam (JHI). Vol. 9, No, 2, 170-188.

Mulawarman, A. D. (2005). Menuju Rekontruksi Teknologi Integralistik Akuntansi Syari"ah:Shari'ate value Addes Statement. Thesis tidak dipublikasikan. Program Studi Akuntansi Minat Akuntansi Syariah. Universitas Brawijaya. Malang.

Muliya, L.I, dan Imaniyati, N.S. (2008). Perusahaan Modal Ventura Dalam Perspektif Hukum Bisnis Dan Hukum Islam. Penerbit Fakultas Hukum Universitas Islam Bandung. Bandung.

Muheramtohadi, S. (2017). Peran Lembaga Keuangan Syariah Dalam Pemberdayaan UMKM di Indonesia. Muqtasid, Jurnal Ekonomi dan Perbankan Syariah. Vol 8(1), No. 94-112.

Nur. M. (2015). Pergulatan Syariahisasi Kerangka Konseptual Akuntansi Di Indonesia. Disertasi. Program Doktor Ilmu Akuntansi. Universitas Brawijaya. Malang

Pasaribu, C. Suhrawadi K.L. (1994). Hukum Perjanjian Dalam Islam. Sinar Grafika. Cetakan ke 1. Jakarta

Rachmawati. (2017). Studi Fenomenologi Atas Implementasi Akuntansi Berbasis Akrual Pada Badan Layanan Umum Daesrah RSUD Dr. Saiful Anwar Malang. Thesis tidak dipublikasikan. Program Magister Akuntansi. Pascasarjana Fakultas Ekonomi dan Bisnis Universitas Brawijaya Malang.

Riharjo, I.B. (2011). Memahami Paradigma Penelitian Non-Positivisme Dan Implikasinya Dalam Penelitian Akuntansi. Jurnal Akuntansi, Manajemen Bisnis Dan Sektor Publik (JAMBSP). Vol. 8, No. 1 128-146.

Susamto, B. (2013). Koperasi Syariah dan Pengaturannya di Indonesia. UIN Maliki Press. Cetakan ke 2. Indonesia.

Santoso, H. (2016). Pelaksanaan Keadilan Upah Bagi "Pekerjaan Malam Wanita". Thesis tidak dipublikasikan. Program Magister Akuntansi. Pascasarjana Fakultas Ekonomi dan Bisnis Universitas Brawijaya Malang.

Soedarso, E.H. (2011). Membangun Konsep Penilaian Kinerja Koperai Syari'ah Berdasarkan Perspektif Shari'ate Enterprise Theory. Thesis tidak dipublikasikan. Program Magister Akuntansi. Pascasarjana Universitas Brawijaya Malang. 


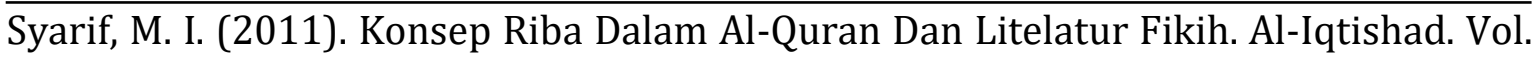
III, No.2.

Susila, A.A. (2014). Strategi Kesuksesan Koperasi BMT Maslahah Dalam Pengembangan Usaha dan Pemberdayaan Ekonomi Umat. Tesis. Gelar Magister Dalam Ilmu Ekonomi Islam. Program Studi Hukum Islam Konsentrasi Keuangan dan Perbankan Syariah. UIN Sunan Kalijaga. Pascasarjana Yogjakarta.

Undang-Undang Dasar 1945 Pasal 33

Undang-Undang Nomor 25 Tahun 1992 Tentang Perkoperasian

Wildaniyati, A. (2006). Penerapan Prinsip Good Corporate Governance Pada Unit Usaha Syariah. Thesis tidak dipublikasikan. Magister Akuntansi. Fakultas Ekonomi dan Bisnis Universitas Brawijaya Malang.

Dewan Pengurus Nasional Fordebi dan Adesy. (2016). Ekonomi Dan Bisnis Islam, Seri Konsep dan Aplikasi Ekonomi Dan Bisnis Islam. PT. RajaGrafindo Persada. Cetakan ke-1. Jakarta. Indonesia. 